\title{
Hipertenzija kao faktor rizika za nastanak atrijalne fibrilacije
}

\author{
Milan Zlatar ${ }^{1}$, Dragan Matić ${ }^{1}$, Branislava Zlatar², Marija Marjanović ${ }^{3}$, Dario Jelić ${ }^{1}$ \\ ${ }^{1}$ Urgentni centar; Odelenje urgentne kardiologije; Klinički centar Srbije; Beograd, ${ }^{2}$ Gradski zavod za javno zdrav- \\ lje; Beograd, ${ }^{3}$ Klinika za kardiologiju; Centar za ispitivanje, dijagnostiku i lečenje arterijske hipertenzije; Klinički \\ centar Srbije; Beograd
}

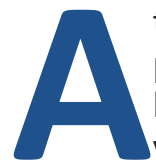
trijalna fibrilacija (AF) je najčešća dugotrajna pretkomorska aritmija u svakodnevnoj kliničkoj praksi i karakteriše je posebno visoka prevalenca kod starijih bolesnika koja se rapidno uvećava sa produženjem životnog veka. AF značajno uvećava stepen mortaliteta i morbiditeta pogotovo zbog petostrukog povećanja rizika od nastanka moždanog udara i embolijskih događaja kao i zbog štetnih hemodinamskih efekata koji često dovode do srčane slabosti, a prosečna dužina života kod bolesnika sa AF iznosi 75 godina. ${ }^{1}$ Definiše se neusklađenom depolarizacijom pretkomora sa poremećajem mehaničke funkcije i nepravilnom te promenljivom frekvencijom komora. AF je najčešće povezana sa arterijskom hipertenzijom te posledičnom hipertrofijom leve komore, starenjem, dijabetesom, srčanom slabošću, preležanim infarktom miokarda i drugim strukturnim oboljenjima srca, a posebno oboljenjima srčanih zalistaka. U poslednjih nekoliko godina sve je više dokaza da pojedina stanja povećavaju rizik za nastanak AF među kojima se najčešće navode: oboljenja štitaste žlezde, hronična bubrežna slabost, gojaznost, stalno i povećano konzumiranje alkohola. Pored stabilizacije hemodinamskog stanja i usporenja srčane frekvencije te ponovnog uspostavljanja sinusnog ritma, osnovni princip lečenja predstavlja prevencija moždanog udara i drugih tromboembolijskih komplikacija (TEK). Za prevenciju moždanog udara se koristi oralna antikoagulantna terapija (varfarin, acenokumarol, dabigatran, rivaroksaban, apiksaban) i antiagregaciona terapija (aspirin, klopidogrel) u zavisnosti od procene stepena rizika.

Najčešći faktori rizika za nastanak atrijalne fibrilacije prikazani su na Tabeli 1.

Povećana pretkomora tj. uvećanje njene površine pogoduje stvaranju uslova za elektrofiziološke fenomene koji dovode do nastanka AF. Pored uvećanja pretkomora, nastanku AF doprinosi i povećanje pritiska u pretkomori, lokalne promene u miofibrilima pretkomora (ishemija, elektrolitni disbalans te promene $u$ tonusu vegetativnog nervnog sistema). Nastajanju AF pogoduju i hipertrofija pretkomora kao i fibrozne degenerativne promene uzrokovane starenjem.

Mnogobrojna oboljenja koja su najčešće povezana sa AF mogu se podeliti na srčana i nesrčana. U srčana spadaju: hipertenzija, oboljenja srčanih valvula, koronarna bolest srca, sve vrste kardiomiopatija, oboljenja perikarda, intrakardijalne mase, oboljenja sprovodnog sistema srca, skorašnja kardiotorakalna operacija i kongenitalna oboljenja srca. Nesrčana oboljenja su: oboljenja neurovegetativnog sistema (simpatikus i parasimpatikus), izlaganje toksinima i otrovima, infekcije ,endokrinopatije (najčešće oboljenja štitaste žlezde), oboljenja pluća i neurološka oboljenja. U 30-50\% slučajeva se javlja Loun (Lone) ili idiopatska AF koja neam jasan uzrok. lako se ranije smatralo da predstavlja benigno oboljenje, Pariska prospektivna studija je dokazala da je relativni rizik za kardiovaskularni mortalitet i totalni mortalitet kod ovog oblika AF značajno povišen. ${ }^{8}$ Češće se javlja kod osoba mlađih od 50 godina i smatra se da je njen nastanak uzrokovan idiopatski povećanom ekscitabilnošću miokarda pretkomora ili promenama na ćelijskom nivou koje se genetski nasleđuju. Takođe je dokazano je postojanje miofibrila u pulmonalnim venama čija prevremena depolarizacija pokreće AF.

Epidemiološke studije su dokazale da učestalost AF iznosi $0,5-1 \%$ u opštoj populaciji mlađih od 60 godina te da je $4 \%$ ljudi starijih od 60 godina imalo epizodu AF, a značajan porast prevalence je dokazan kod osoba starijih od 70 godina.

Framingamska (Framingham) studija je ustanovila incidencu AF od 2\% kod bolesnika starijih od 22 godine, sa nešto većom učestalošću kod muškaraca u odnosu na žene..$^{1,6} \mathrm{U}$ istoj studiji je potvrđeno da je rizik od nastanka AF tokom života kod muškaraca starijih od 40 godina iznosio $26 \%$, dok je kod žena iznosio $23 \%$.

Slične rezultate je potvrdila i Roterdamska studija, iz čega se može zaključiti da rizik nastanka AF kod bolesnika starijih od 40 godina iznosi 1 prema $4 .^{7}$

U Framingamskoj studiji su ispitivane kliničke karakteristike bolesnika starosti od 55 od 94 godine kod kojih se razvila $\mathrm{AF}$ tokom 40 godina praćenja. Od 5209 bolesnika na početku studije, AF je ustanovljena kod 296 muškaraca i 325 žena. Bolesnici sa AF su na početku praćenja češće imali hipertenziju, elektrokardiografske znake hipertrofije leve komore, preležan infarkt miokarda, kongestivnu srčanu slabost, valvularne srčane mane, cerebrovaskularne bolesti. Ova studija je ustanovila da je AF povezana sa relativnim rizikom od smrtnog ishoda koji iznosi 1,5 kod muškaraca i 1,9 kod žena. (1) 
Tabela 1. Faktori rizika, klinička stanja i biomarkeri odgovorni za nastanak atrijalne fibrilacije

\begin{tabular}{|c|c|c|}
\hline Tradicionalni faktori rizika & Novi faktori rizika & Biomarkeri \\
\hline Godine, muški pol & Redukovana vaskularna komplijansa & Povećana arterijska krutost \\
\hline Hipertenzija/Dijabetes melitus & Ateroskleroza & Produženo trajanje QRS kompleksa \\
\hline Konzumiranje alkohola/pušenje & Insulinska rezistencija & Depresija $\mathrm{p}$ talasa \\
\hline Klinička stanja & Faktori okoline (zagađenost vazuha itd.) & Niska telesna masa na rođenju \\
\hline Hipertrofija leve komore & Višak vitamina $\mathrm{D}$ & Inflamatorni markeri \\
\hline $\begin{array}{l}\text { Miokardni infarkt/srčana } \\
\text { insuficijencija }\end{array}$ & Atrijalna fibroza & Neurohormoni \\
\hline Valvularna srčana obolenja & Aritmogeni agensi & Genetske varijacije \\
\hline Bolest štitaste žlezde & Ekstremno vežbanje & Pulsni pritisak \\
\hline $\begin{array}{l}\text { Prethodna kardijalna hirurgija/ } \\
\text { post-kardijalna hirurgija }\end{array}$ & Inflamacija, oksidativni stres & Tireoidni stimulišući hormon, T3, T4 \\
\hline Kongenitalna srčana obolenja & Opstruktivna apnea tokom spavanja & Atrijalni natriuretski peptid \\
\hline Kardiomiopatije & Gojaznost/metabolički sindrom & Visoko senzitivni C reaktivni protein \\
\hline Nasledne kanalopatije & Zagađenost vazuha & Interleukin-6 \\
\hline $\begin{array}{l}\text { Poremećaj autonomnog nervnog } \\
\text { sistema }\end{array}$ & Giht & Angiotenzin II \\
\hline Hronična bubrežna bolest & & Markeri fibroze \\
\hline Elektrolitni disbalans & & mRNA \\
\hline \multicolumn{3}{|l|}{ Oboljenje pluća } \\
\hline \multicolumn{3}{|l|}{ Ehokardiografski prediktori AF } \\
\hline & & Frakciono skraćenje leve komore \\
\hline & & Kalcifikcija mitralnog prstena \\
\hline & & Uvećanje leve pretkomore \\
\hline & & $\begin{array}{l}\text { Hipertrofija leve komore } \\
\text { (zadebljanje zida leve komore) }\end{array}$ \\
\hline
\end{tabular}

Modifikovano iz Shenasa M, Camm AJ. Management of Atrial Fibrillation. A Practical Approach. Oxford University Press, 2015.

Hipertenzija ili povišeni krvni pritisak je hronična bolest kod koje je krvni pritisak u sistemskim atrerijama trajno povišen i prelazi vrednosti od $140 \mathrm{~mm} \mathrm{Hg}$ za sistolni i 90 $\mathrm{mm} \mathrm{Hg}$ za dijastolni krvni pritisak u mirovanju.

U razvijenim zemljama arterijska hipertenzija je najčešće patološko stanje koje prati $A F$, odnosno smatra se najčešćim uzrokom atrijalne fibrilacije (AF), te zbog izuzetno visoke prevalencije najviše doprinosu nastanku $A F$ u poređenju sa drugim faktorima rizika. ${ }^{1}$ Hipertenzija uvećava mogućnost nastanka AF za 40-50\%. Dokazano je da prisustvo hipertenzije uvećava rizik za nastanak $A F$ za 1,5 puta kod muškaraca i 1,4 puta kod žena. ${ }^{2} U$ nekim istraživanjima je dokazano da pored povišenog krvnog pritiska i srednjeg arterijskog krvnog pritiska, čak i granične vrednosti dijastolnog krvnog pritiska od $90 \mathrm{~mm}$ živinog stuba predstavljaju faktor rizika za nastanak AF. Rizik nastanka AF kod bolesnika sa hipertenzijom i bez dodatnih faktora rizika se povećava sa starenjem te sa uvećanjem mase leve komore. ${ }^{4}$ Takođe kod bolesnika sa hipertenzijom i hipertrofijom leve komore znatno češće nastaje AF u poređenju sa bolesnicima sa hipertenzijom bez hipertrofije leve komore.

Treba napomenuti da skoro trećina bolesnika sa AF i arterijskom hipertenzijom nema nikakve simptome. AF i hipertenzija su zajedno prusutne kod $72 \%$ bolesnika obolelih od moždanog udara, $83 \%$ bolesnika sa hroničnom bubrežnom slabošću, $77 \%$ bolesnika sa dijabetesom, $73 \%$ bolesnika sa hroničnom slabošću srca i kod $62 \%$ bolesnika sa metaboličkim sindromom. Hipertenzija je dijagnostikovana u rasponu od $49-90 \%$ bolesnika sa AF koji su učestvovali u različitim studijama. ${ }^{5}$ Hipertenzivna bolest srca obuhvata negativne promene u kardiovaskualrnom sistemu koje nastaju usled dugogodišnjeg povišenog krvnog pritiska. Ove promene obuhvataju: hipertrofiju leve komore srca, uvećanje leve pretkomore, dijastolnu disfunkciju, nastanak slabosti mitralne valvule uz posledičnu regurgiticiju i neurohormonalne promene.

Proaritmične patoanatomske promene u miokardu i endokardu (hipertrofija pretkomora i komora, pojačan pritisak na zidove pretkomora) te posledično poremećeni neurohormonalni procesi (aktivacija renin-angiotenzin-aldosteron sistema) koji dovode do zapaljenskih reakcija te fibroze uzrokuju češći nastanak AF kod hipertoničara. Pored navedenih procesa, proatrimijsko destvo ima zasigurno i antihipertenzivna terapija i to pre svega usled olakšanog nastanka hipokalemije.

Sa druge strane, adekvatna kontrola hipertenzije, koja uključuje blokadu renin-angiotenzin- aldosteron sistema preko blokatora angiotenzinskih receptora ili inhibitora 
angiotenzin konvertujućeg enzima, značajno usporava remodelaciju pretkomora i tako sprečava pojavu AF. U mnogobrojnim studijama je dokazano je da je antihipertenzivna terapija koja smanjuje hipertrofiju leve komore povezan sa smanjenom učestalošću AF.

Pored direktne povezanosti sa nastankom AF, neadekvatno lečena hipertenzija predstavlja glavni faktor rizika za nastanak moždanog udara i sistemskih embolijskih komplikacija čak i kod bolesnika koji primaju antikogulantnu terapiju. Takođe treba napomenuti da novonastala AF kod bolesnika sa hipertenzijom i hipertrofijom leve komore uveća rizik od nastanka iznenadne tj. naprasne srčane smrti kao i moždanog udara, nezavisno od ostalih faktora rizika ${ }^{10}$.

Takođe, nelečena hipertenzija dovodi do oštećenja srčanog mišića te do nastanka posledične srčene slabosti. Adekvatno lečenje hipertenzije ima nemerljiv doprinos u sprečavanju nastanka AF i prevenciji nastanka i pogoršanja srčane slabosti i ishemijskog moždanog udara, pogotovo što hipertenzija danas predstavlja oboljenje koje se često podcenjuje i čije se lečenje ne započinje na vreme.

\section{Literatura}

1. Benjamin EJ, Wolf PA, D'Agostino RB, Silbershatz H, Kannel WB Levy D. Impact of atrial fibrillation on the risk of death: the Framingham Heart Study. Circulation. 1998; 98(10): 946-52.

2. Benjamin EJ, Levy D, Vaziri SM, D'Agostino RB, Belanger AJ, Wolf PA. Independent risk factors for atrial fibrillation in a population- based cohort. The Framingham Heart Study. JAMA. 1994; 271: 840-844.

3. Grundvold I, Skretteberg PT, Liest $\varnothing \mid$ K, Erikssen G, Kjeldsen SE, Arnesen H, Erikssen J, Bodegard J. Upper normal blood pressures predict incident atrial fibrillation in healthy middle-aged men: a 35-year follow-up study. Hypertension. 2012; 59(2): 198-204.

4. Verdecchia P, Reboldi G, Gattobigio R, Bentivoglio M, Borgioni C, Angeli F, Carluccio E, Sardone MG, Porcellati C. Atrial fibrillation in hypertension: predictors and outcome. Hypertension. 2003; 41(2): 218-23.

5. Manolis AJ, Rosel EA, Coca A, Cifkova R, Erdine, SE, Kjeldsen S, et al. (2012). Hypertension and atrial fibrillation: diagnostic approach, prevention and treatment. J Hypertens 30: 239-52.

5. Manolis AJ, Rosei EA, Coca A, Cifkova R, Erdine SE, Kjeldsen S, Lip GY, Narkiewicz K, Parati G, Redon J, Schmieder R, Tsioufis C, Mancia G. Hypertension and atrial fibrillation: diagnostic approach, prevention and treatment. Position paper of the Working Group 'Hypertension Arrhythmias and Thrombosis' of the European Society of Hypertension. J Hypertens. 2012; 30(2): 239-52.

6. Lloyd-Jones DM, Wang TJ, et al. Lifetime risk for development of atrial fibrillation: the Framingham Heart Study. Circulation. 2004 ; 110: 1042-1046.

7. Heeringa J, van der Kuip DA, et al. Prevalence, incidence and lifetime risk of atrial fibrillation: the Rotterdam study. Eur Heart J. 2006; 27: 949-953.

8. Jouven $\mathrm{X}$, Desnos $\mathrm{M}$, et al. Idiopathic atrial fibrillation as a risk factor for mortality: the Paris Prospective Study I. Eur Heart J. 1999; 20: 896-899.

9. Raman SV. The hypertensive heart: an integrated understanding informed by imaging. J Am Coll Cardiol. 2010; 55: 91-96.

10. Okin PM, Wachtell K, Devereux RB, Harris KE, Jern S, Kjeldsen SE, et al. Regression of electrocardiographic left ventricular hypertrophy and decreased incidence of new-onset atrial fibrillation: the LIFE study. JAMA. 2006; 296: 1242-8. 